\title{
Pragmalingwistyczne aspekty not dyplomatycznych. Przyczynek
}

\author{
Agata Wolarska-Sobocińska \\ INSTYTUT JĘZYKOZNAWSTWA, UNIWERSYTET IM. ADAMA MICKIEWICZA \\ AL. NIEPODLEGŁOŚCI 4, 61-874 POZNAŃ \\ agata.wolarska@amu.edu.pl
}

\section{Streszczenie}

Problematyka korespondencji dyplomatycznej, której przejawem są noty dyplomatyczne wpisuje się w nurt badań typologicznych, genologicznych (genologia lingwistyczna), pragmatycznych/pragmalingwistycznych (i strukturalnych nad językiem) oraz socjolingwistycznych. Noty dyplomatyczne to ważny element współczesnej dyplomacji, definiowany przez Juliana Sutora jako: (...) gtówny instrument komunikacji urzędowej między rządami państw. [Sutor, 2008: 19]. W zależności od charakteru i cech formalnych oraz osób nadawcy i odbiorcy możemy wyróżnić kilka rodzajów not dyplomatycznych. Przedmiotem analizy jest nota werbalna jako najbardziej powszechna forma not dyplomatycznych. 